\title{
The Integration of Economics and the Environment through Incentives: An Overview of the Costa Rican Success Story
}

\author{
J N Blignaut \\ Department of Economics, University of Pretoria
}

\section{H J Anderson}

Centre for Scientific and Industrial Research, Pretoria

\begin{abstract}
Conservation is often perceived as the responsibility of the landowners. If landowners fail to benefit from conservation, they inevitably view it as profiteroding and it becomes less attractive than alternative land-use practices. Costa Rica has successfully internalised the benefits provided by forestry environmental services. Valuable lessons could be learnt from the Costa Rican experience in using economic incentives for environmental management.
\end{abstract}

JEL Q23, Q28

\section{INTRODUCTION}

Failure to internalise the benefits of conservation results in conservation being viewed as mainly an expenditure item that should be borne by the landowners, both public and private. This causes landowners to perceive conservation as a cost that reduces profits, and thus potentially their sustainability as a business. The inability of landowners to benefit from the environmental services provided by their land causes them to invest in other land use practices where their economic and financial return is greater. In developing countries, where rural communities depend on the natural environment for their survival, the situation is especially troubling. This is so since the continuous use of the environment not only threatens the sustained delivery of ecological services, but the reduction of natural resources implies less livelihood means (Anderson \& De Wit, 2002).

The above scenario was also evident in Costa Rica, but after decades of deforestation, bold steps have been taken to internalise the benefits provided by forestry environmental services (see Castro, 1999; Castro et al., 2000 and 
Chomitz et al., 1999). This paper focuses on the Costa Rican experience in using economic incentives for environmental management, with the purpose of making recommendations for South Africa on how to go about capturing the value of its environmental services.

\section{COSTA RICA IN A NUTSHELL}

Costa Rica is a predominantly Spanish speaking Latin American country covering $51000 \mathrm{~km}^{2}$ (compared to South Africa's 1.2 million $\mathrm{km}^{2}$ ), initially almost all covered by tropical forest. It has a population of approximately 3.6 million, and its economy currently relies on tourism and the production of bananas and coffee. Costa Rica's forests are rich in biodiversity, and despite its small size, Costa Rica contains an estimated 4 per cent of the world's species (Chomitz, Brenes \& Constantino, 1999). The country has a stable democracy, with an inflation rate of approximately 17 per cent (IMF, 2000) and an annual GDP per capita of US\$4 194 in 1999 (World Bank, 2001). The World Bank classifies Costa Rica as a lower middle-income country whereas South Africa is classified as an upper middle-income country. From this evidence it is clear that Costa Rica is not more wealthy than South Africa. Rather the contrary; the problems that it faces are perhaps even more daunting.

\section{MOTIVATION FOR THE USE OF ECONOMIC INCENTIVES AS AN ENVIRONMENTAL MANAGEMENT TOOL}

\subsection{Deforestation in Costa Rica}

While in 1950 more than half of Costa Rica had been covered by forest, by 1986 merely 29 per cent of the country was still covered by forests. The decades of deforestation had been driven by rapid expansion of the road system, cheap credit for cattle and land titling laws that rewarded deforestation. The underlying policies that supported the harvest of the forests are embedded in the conventional wisdom that growth in man-made capital equates development and indicates progress. This implies a tax on the environmental services rendered by forests vis-à-vis man-made capital, or, viewed differently, that the investment in man-made capital was subsidised due to the inappropriate valuation of forestry services. This is also proven by the fact that agriculture, and especially pasture, had replaced forest cover, and of the 35 per cent pastureland only 8 per cent is believed to be suitable for that use (Chomitz et al., 1999). 


\subsection{Forestry environmental services}

After the results from a national land cover survey in 1979 had become available, Costa Rican authorities realised drastic measures were necessary to reduce the rate of deforestation. This decision was based on a new understanding that it was necessary to preserve forests because of the many environmental services that they provided. These include: biodiversity or the diversity of species, hydrological services, carbon sequestration, eco-tourism and scenic views. It is important to conserve biodiversity for its bioprospecting value (various products use material from natural flora and fauna, including perfumes, cosmetics, pesticides and pharmaceutical products), eco-tourism value, and for its ecosystem services, such as the provision of healthy habitats for animals. Well-functioning watersheds also provide important hydrological services since the loss of forests in important watershed areas may result in soil erosion and subsequent sedimentation in rivers and streams. This sedimentation can reduce the quality of drinking water and cause losses in hydroelectric production potential. It also increases the risk of flooding, which in turn may result in further losses in potential electricity generation (Chomitz et al., 1999). The loss of forest cover has therefore very real economic cost implications over and above the services that forests provide.

Forests and woodlands provide valuable carbon sequestration services. Carbon sequestration can be seen as the direct removal of from the atmosphere, and the subsequent long-term storage of carbon dioxide. Through the maintenance of primary forests, and the promotion of plantations or secondary growth, the Costa Rican landowners assist in the reduction of atmospheric concentrations of carbon dioxide, thus reducing the negative economic impacts of climate change (Anderson \& De Wit, 2002).

\subsection{Valuing the natural wealth of forests}

Given the new understanding of the services forests render and that the presence of forests can prevent damage to man-made capital, attempts have been made to estimate the average annual value per hectare of forestry environmental services. However, this is not simple, due to the fact that there are no relevant markets within which to capture the value of these services. Furthermore, the value of forestry services varies among different plots, in accordance with the ecological features of each. In Table 1 are Kishor and Constantino's (1993) estimates of these ecological values. It is clear that values for carbon sequestration are quite large and dominate the values for the other services. 
Table 1 Estimated environmental values of primary forests (in 1989, sUS/ha)

\begin{tabular}{|l|c|}
\hline \multicolumn{1}{|c|}{ Type of Benefit } & $\begin{array}{c}\text { Average Annual } \\
\text { Value }\end{array}$ \\
\hline 1. Hydrologic benefits & $2.3-4.6$ \\
a) water supply for urban centers & $10-20$ \\
b) loss of hydroelectric production potential & $0.25-2.0$ \\
c) protection of agricultural land & $\underline{4-9}$ \\
d) flood control & $\sim 17-36$ \\
Total & $60-120$ \\
\hline 2. Carbon sequestration & $\sim 13-25$ \\
\hline 3. Ecotourism (non-consumptive use values) & 0.15 \\
\hline 4. Future pharmaceuticals (option values) & $\sim 13-32$ \\
\hline 5. Funds transfers (existence and option values) & $\sim 102-214$ \\
\hline Total & $\sim 1277-2671$ \\
\hline Net present value at 8\% & \\
\hline
\end{tabular}

Source: Castro, Tattenbach, Gamez \& Olson, 2000, originally adapted from Constantino \& Kishor, 1993

Having realised the importance of their forests and in an effort to protect then, Costa Rica has developed legal instruments and institutional arrangements that allow the internalisation of these benefits. Landowners now have an incentive to conserve their forests and safeguard the integrity of their land.

\section{DEVELOPING THE RELEVANT LEGAL AND INSTITUTIONAL REGIMES}

The mid-1990s saw the establishment of a remarkable set of innovative institutions to harness the new philosophy described above. The key legal instrument was a new forestry law, Ley Forestal \#7575, adopted in 1996. This law recognises the value of the ecological services rendered by forests and provides the legal and regulatory basis to compensate forest owners for the environmental services offered by their lands.

The law addresses four key environmental services provided by forests: carbon fixation, watershed protection, biodiversity and protection of natural forest ecosystems in life zones of particular importance. Subject to certain provisions, such as a certified forestry management plan, this empowers the Forestry Authority to contract with forest owners, and to compensate them for the 
environmental services their lands offer (Castro, Tattenbach, Gamez \& Olson, 2000).

To coincide with the new Forestry Act, 1996 also saw the establishment of the Costa Rican Office for Joint Implementation (OCIC). This office had the authority to formulate policy for Joint Implementation (JI) and Activities Implemented Jointly (AIJ) programmes and reports to the Ministry of Environment and Energy (MINAE). The office established project approval criteria and originally assisted in the development of over 15 project proposals. More recently, its strategy has exclusively been to promote three national projects, focusing on the consolidation of parks (Protected Areas Project), natural forest management (Private Forestry Project) and renewable energy. These national-scale projects reduce the transaction costs associated with developing and marketing projects. These costs constitute one of the biggest obstacles to developing countries wishing to participate in JI and AIJ (Castro et al., 2000).

The National Forestry Financing Fund (FONAFIFO) was established within the environmental ministry (MINAE) in 1991 to provide incentives and loans for reforestation. In 1997, however, based on the new forestry act and the JU/AIJ office, FONAFIFO became involved in managing the domestic administration and finances of the national forestry incentives, and in executing payments to landowners under the forestry environmental services program (FESP) (Castro et al., 2000).

Thus, by 1997, several institutions saw to it that landowners were compensated for the benefits that their land provided. Incidentally, 1997 was also the year of the Kyoto meeting and Costa Rica was therefore ready to take advantage thereof.

\section{HOW THE SYSTEM FUNCTIONS}

\subsection{Forestry environmental services program}

By 1998, the payment for forestry environmental services program (FESP) compensated three types of activities: reforestation, natural forest management and forest protection; and provisions were made for a fourth activity, namely forest regeneration. In return for the payments, the landholders had to cede their carbon and other environmental service rights to FONAFIFO for five years, whereas they promised to manage or protect the forest for a period of 20 years (or 15 in the case of reforestation). This obligation was registered in the public land register and would apply to any future purchasers of the land. 
Monitoring is currently the responsibility of each participant's supervising forester (who was also responsible for drawing up the forestry management plan for the property) (Chomitz et al., 1999).

At present three payment levels exist, one for each type of activity under FESP (Chomitz et al., 1999). The main competitive land use with which the FESP must compete is the grazing of cattle livestock, as pastureland accounts for one third of the country. The opportunity cost approach values the benefits of environmental protection in terms of what is being foregone to achieve it (Garrod \& Willis, 1999). This approach forms the basis for estimating value of the compensation payments. It is thus relevant to ask what the opportunity cost would be to cattle ranchers if they were to dedicate their land to the FESP. Analysis has indicated that the cattle sector has shown profits of between US\$8 and US\$125 per hectare per year, depending on such aspects as management and ranching practices and land characteristics and location. Thus, it is clear that most landowners would switch to reforesting their land under the FESP program, as under this they are offered US\$96 per hectare per year (assuming an approximate exchange rate of 250 colones/US\$, March 1998) (Chomitz et al., 1999). Similarly, if a landowner within the Cordillera Central area had been renting a hectare of pasture at the current average rate of US\$20 to US\$30 for that area (Castro et al., 2000), he would be financially better off by conserving the remainder of the natural forest on his land. This is based on an incentive payment of US $\$ 40$ per hectare per year for forest protection, under the FESP program (Chomitz et al., 1999).

Castro (1999) for instance has found that the annual rent necessary to switch from coffee to forest protection was $\$ 1186$ per hectare per year for a farm just outside of La Amistad. This demonstrates the variability in the productive value of land that could be earmarked for conservation. This also highlights the dilemma created by the current three fixed payments for the different forestry activities within FESP, which do not take into account the marginal value of the land. It is believed that the program has had substantial excess demand for participation, which is a clear indication as to the level of general acceptance by the landowners of the programme. Since there is a surplus supply, the applications need to be prioritised. These prioritisation criteria include: hydrological importance, significant biodiversity and close proximity to existing protected areas.

A program such as this, which involves a number of micro enterprises and activities on grassroots level, involves substantial transaction costs, making participation for smallholders relatively more expensive. A number of NGOs have therefore adopted the role of intermediary between government and 
landowners; they also bundle together collections of smaller, individual projects (Chomitz et al., 1999).

\subsection{Financing environmental services payments}

The main source of funding for the FESP is a tax of 15 per cent on fuel sales, dedicated to the reduction of greenhouse gases and the protection of biodiversity, established under Ley 7575 in 1996. One third of this (5 per cent) is dedicated to forestry through FONAFIFO (Chomitz et al., 1999).

In addition, MNNAE established a Carbon Fund in 1997 to distribute 'rights' or 'credits' in exchange for monetary deposits from domestic and international sources. The Carbon Fund will also be able to finance JI/AIJ activities, while FONAFIFO can only compensate private landowners for environmental services (Castro et al., 2000).

The secondary source of funding is the sale of Certifiable Tradable Offsets (CTO) (the Costa Rican version of a certifiable emission reduction (CER)), a financial instrument designed by Costa Rica to transfer (sell) greenhouse gas (GHG) offsets in the international market. The offset amount is the difference between the actual carbon emissions and the baseline emissions, i.e. those that would have been emitted in the absence of the project. This is expressed in carbon equivalent units sequestrated (Chomitz et al., 1998). The Costa Rican verification process certifies CTOs, although investor confidence could be strengthened if a third party monitoring the certification process were to be established. CTOs are pre-approved; thus they should appeal to investors who wish to avoid the costs of developing and submitting a JI project for evaluation. CTOs are also fully transferable and guaranteed by MINAE for 20 years (Castro et al., 2000).

The operation of FESP is shown in Figure 1. From this diagram it is clear that landowners sell offsets (environmental services) to the national forestry financing fund and are, in turn, compensated for these offsets. The funds to pay for the offsets originate from firstly the fossil fuel tax levy and secondly the carbon or greenhouse fund. 
Figure 1 The forestry environmental services payment scheme

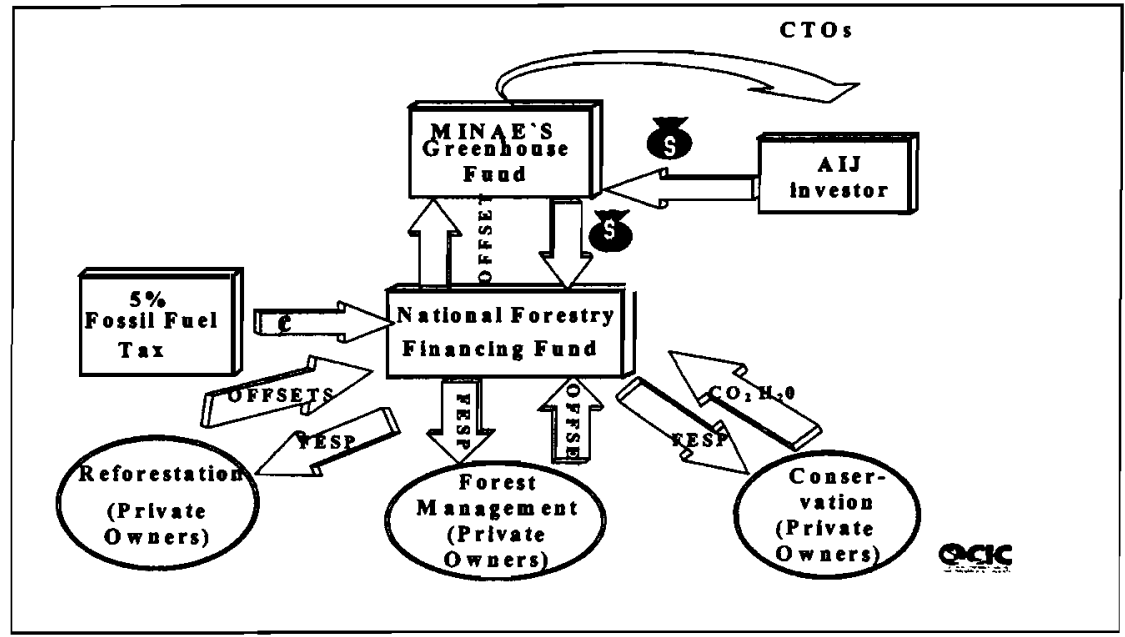

Source: Castro et al., 2000

\section{FINANCIAL IMPACTS AND INITIAL CAPITAL FLOWS}

Based on the scheme discussed above, the following initial transactions took place:

- July 1996 saw Costa Rica's first sale of CTOs. Costa Rica signed a contract with Norway, for US\$2 million worth of carbon sequestration services, at US\$10/ton. The money contributed to the Private Forestry Project, and more specifically to the expansion and reconstruction of a hydroelectric facility.

- A cooperation project with the Dutch government was the first non-carbon sequestration CTOs project. This project involved the anaerobic treatment of organic waste from coffee processing, resulting in annual reductions of 500 tons in methane emissions.

- The Centre for Financial Products, launched at the Chicago Board of Trade (in 1993) is promoting the development of the CTO market. The Centre has a contract to broker four million tons of Costa Rican carbon over the next twenty years. This will generate over US\$40 million in revenues.

- Furthermore, two major bioprospecting agreements have together resulted in funding of US\$4million to INBio, Costa Rica's National Institute of Biodiversity (Castro et al., 2000). 
- The success of the Costa Rican forestry incentive program has also encouraged the World Bank and the Global Environment Facility (GEF) to finance the Eco-markets project. This project aims to support the development of markets at the local level for the forestry environmental services, at the regional and national level for energy, and at the global level for carbon offsets.

- Most recent is the proposed Fund for Renewable Energy (FRER), which aims to support the development of small renewable energy projects to meet increased demand for energy within Costa Rica and its neighbouring countries (Project Idea Note, 2000).

\section{LESSONS FOR SOUTH AFRICA}

From the experience of Costa Rica, it is clear that a small developing country can make an international contribution to the reduction in GHGs through the protection of environmental services and contribute to local development simultaneously. Costa Rica showed that small- and large-scale sustainable forestry that includes rewards for environmental services is viable and feasible.

A country wishing to develop an environmental services payment scheme faces a number of challenges. These include: adequate finance; deciding on an equitable payment structure; the additionality requirement (which involves establishing which offsets are additional to the business as usual-scenario); lastly, recognising that the environmental services provided by properties differ in quality and quantity, and also that costs of participation can differ dramatically.

Some specific factors that must be considered by South Africa when seeking to implement an environmental services payment scheme are the following:

- Landowners have implicit rights to take actions that could result in carbon dioxide emissions and biodiversity loss. Landowners provide environmental services by refraining from these actions, which is in contrast with the polluter pays principle (Chomitz et al., 1999). South Africa must therefore define its property rights and environmental services.

- Landowners could in principle sell each service independently in different markets, but there are strategic and practical advantages to having a monopsonist, who purchases all the landowner's services and resells them on the domestic or foreign markets. (In Costa Rica this role is held by FONAFIFO.) A strategic advantage is that the monopsonist can appropriate 
some of the rents, and use this revenue to secure, for example, biodiversity services, which may not have a market (Chomitz et al., 1999).

- If a monopsony is used, a pricing strategy must be defined. The choice here is between fixed and differentiated prices. The FESP program adopted the fixed price approach, due to its simplicity and appearance of equity. However, if prices are set high enough this can generate excess demand for participation, and would-be-participants need to be prioritised. Fixed prices may also be socially and fiscally inefficient, and may cause favourable properties, needed for watershed protection, not to enrol in the program (Chomitz et al., 1999). Alternatively, differentiated pricing can be used. This would enable properties to be compensated for the bundle of services they provide. This scheme achieves social efficiency, but does not yield excess revenues for the implementing agency, unless an administration fee is added. Another option would be to hold a reverse auction, where the implementing agency's budget is revealed and property holders bid for placing their property under protection. The agency can then finance the lower bids first or apply a prioritisation criteria (Chomitz et al., 1999).

- A prioritisation strategy will be necessary regardless of the pricing strategy, as biodiversity preservation cannot be left to an entirely decentralised or market-orientated approach. Different priority-setting systems exist, that weigh various criteria, or benefits and costs, thus developing an appropriate scoring system. An example of this is the US Conservation Reserve Program's Environmental Benefits Index (Chomitz et al., 1999).

\section{CONCLUSION}

After decades of deforestation, Costa Rica has taken bold steps to internalise the benefits provided by forestry environmental services. They have developed the necessary legal and institutional regimes, thus enabling landowners who choose to conserve or reforest their land to benefit from their actions by receiving financial payments.

This indicates that creative and innovative thinking coupled with the boldness to act upon it through the establishment of an appropriate institutional and operational infrastructure can have major consequences. South Africa can only gain from such an approach.

The challenge for South Africa is to develop its own version of a conservation cum development scheme. This scheme would have to encourage landowners and producers to limit their environmental footprint and to market the environmental services of the rich biodiversity of South Africa, whilst developing the country. 


\section{REFERENCES}

1 ANDERSON, H.J. \& DE Wit, M.P. (2002) "Capturing the Value of Environmental Services: Lessons for South Africa", CSIR. Report No. ENV-P-C 2002-007.

2 CASTRO, R. (1999) "Valuing the Environmental Service of Permanent Forest Stands to the Global Climate: The Case of Costa Rica", Unpublished Doctoral Thesis.

3 CASTRO, R., TATTENBACH, F., GAMEZ, L, \& OLSON, N. (2000) "The Costa Rican Experience with Market Instruments to Mitigate Climate Change and Conserve Biodiversity", Environmental Monitoring and Assessment Journal, 61(1): 75-92.

4 CHOMITZ, K.M., BRENES, E. \& CONSTANTINO, L. (1999) "Financing Environmental Services: the Costa Rican Experience and its Implications", Science of the Total Environment, 240(1-3): 57-169.

5 GARROD, G. \& WILLIS, K. (1999) Economic Valuation of the Environment: Methods and Case Studies, Cheltenham: Edward Elgar.

6 IMF (2000) International Financial Statistics (IFS), Washington DC: IMF.

7 PROJECT IDEA NOTE (2000) "Costa Rica: Fund for Renewable Energy of the Ecomarkets Project", Unpublished.

8 WORLD BANK (2001) The Little Green Data Book, from the World Development Indicators, Washington DC: World Bank. 